\title{
Problem of saving resources on Danube rice irrigation systems by re-using drainage-waste waters
}

V. Turcheniuk,

S. Kropyvko,

Candidates of Engineering

A. Rokochynskyi

Doctor of Engineering

National University of Water and Environmental Engineering, Rivne

The purpose. To study opportunity of use of drainage-waste waters (DWW) of rice systems for irrigating rice and companion crops, their influence upon edaphic processes and to develop scientific bases for regulated use of DWW for saving resources and environment. Methods. Field, laboratory-analytical, calculation. Results. Technological scheme of use of DWW of rice systems for irrigating rice and companion crops which ensures saving aqueous and power resources is offered. Conclusions. Results of probes confirm opportunity of use of DWW of Danube rice systems in irrigation farming agriculture under condition of their combined use with fresh water in the ratio $1: 1$ or 1:2. That enables to save aqueous and power resources, and to prevent pollution of aqueous sources.

Key words: drainage-waste waters, rice irrigation system, reuse of DWW.

The main requirements that apply to modern irrigated agriculture, including rice-growing, is getting high, economically feasible agricultural yields, cost minimization, preservation of soil fertility and ecological condition of irrigated lands and adjacent areas [1, 2]. The main resources used for irrigated agriculture, in comparison with dryland farming, are water and energy resources. Due to noticeable deficit of these resources the problem of rational use of fresh water is becoming increasingly important. The reason is in reduction of its supply and in increasing of the amount of slightly mineralized drainage water and wastewater $[3,4]$.

Statement of the problem. One of the most pressing problems that needs to be solved today by operational organizations, is a problem of the use of drainage water and wastewater (DWW) in rice irrigation systems (RIS) [1, 5]. On 1 hectare rice cultivation is used $18-30$ thousands $\mathrm{m}^{3}$ of water, about $50 \%$ of which is spent on filtering and discharges [6]. At rice systems every year is formed and discharged into the gulf of Black and Azov seas about 600 million $\mathrm{m}^{3}$ of water. For example, only in Skadovsk district (Kherson region) annually are discharged into the gulf Dzharylhach up to 170 million $\mathrm{m}^{3}$ of DWW, 110 million $\mathrm{m}^{3}$ of which are with the mineralization up to $1000 \mathrm{mg} / \mathrm{dm}^{3}$ [7]. The annual intake from the Danube in the rice systems was 250 million $\mathrm{m}^{3}$ in the early $70 \mathrm{~s}$ of last century and now reaches 90 million $\mathrm{m}^{3}$. Diversion of drainage discharges into water bodies leads to a partial change of their mineralization, chemical contamination. The experience of most rice systems operating in Ukraine and abroad shows, that the average discharge is 30$70 \%$ of the quantity of water abstracted, supplied for irrigation. Mineralization of such water is usually low and ranges from 0.5 to 3-5 grams per liter. The presence of heavy metals' saults in DWW is the result of their contamination by decay products of herbicides, which are used in rice crop systems.

At the same time the use of DWW can be an important factor, that can provide a significant increase in the area of irrigated land in southern Ukraine without increasing of water intake from sources of irrigation, and reduction of water consumption for irrigation of rice and related crops in rice systems.

The purpose of research is to study the possibility of using DWW for irrigation of rice and related crops in rice systems, their impact on soil processes, and to develop scientific foundations of controlled using DWW in rice systems for resources and environmental conservation. 
Methods of research included the identification of quantitative and qualitative indicators of drainage water and wastewater in RIS, the impact of technology of their use on the yield of rice and on soil processes.

The results of research. In the main rice growing areas today was gained a considerable experience in the effective use of DWW in rice systems [8, 9 and others]. The first studies related to the reuse of drainage

water and wastewater in RIS for irrigation of rice and related crops on the Danube RIS were conducted in the 1967-1980 on Kiliya rice system [10].

The research shows that for most rice systems the use of DWW for watering in the first years of their use isn't possible. It can be explained by mineralization of DWW and their unsatisfactory quality indicators because in the initial period of system operation the desalination process is more intensive. After several years of right operation of rice system, on it comes relatively stable balance between the amount of salts that enter the soil balance and those which are allocated from DWW. During this period of operation DWW systems can be used for irrigation by dilution with fresh water in different proportions, or without such dilution.

When using DWW from rice fields it should be noted that the chemical composition of these water is formed by the dilution of fresh waste water with mineralized groundwater, which are drained by a collectordrainage network. Depending on the ratio of fresh water and DWW in water, which is submitted for irrigation, can be changed their mineralization and chemical composition. Therefore, before using waste water from rice fields to re-irrigation, it is necessary to study their chemical composition and how it changes in time. The first thing to look at while reuse of DWW for irrigation of rice - is the presence in them of toxic for plants water-soluble salts, especially $\mathrm{NaSO}, \mathrm{NaCl}$.

Also should be foreseen the potential for development of alkalinity of rice fields due to an excess amount of $\mathrm{Na}^{+}$ions, which are inserted with irrigation water.

For today in meliorating practice are known such basic techniques of DWW use in rice systems for rice irrigation:

- reuse without flow dilution;

- reuse with flow dilution with irrigated water;

- reuse of DWW with supply in irrigation channels;

- partial reverse use of DWW.

Reuse without flow dilution consists in the fact that the drain from paddy fields, which is irrigated with fresh water, is supplied to the check situated below. Allowable DWW mineralization at such use of it should not exceed $1 \mathrm{~g} / \mathrm{L}$. It is necessary to exercise operational control of water mineralization, which is resupplied to irrigation, and to exercise the change of water salinity in the second check. Failure to comply with such requirements can cause lower yields of rice, because it has a weak salt resistance. In rice systems the drain can be used for irrigation without dilution with fresh water no more than 1-2 times. This technique is extended in Krasnodar region.

Reuse with flow dilution with irrigated water consists in the fact that irrigation water to the first section is supplied fresh. Flow from it, diluted with fresh water, enters the second section, located below. Flow from second section, also diluted, enters the third section etc. In conditions of rice systems in Ukraine, this method has no perspectives because of their design features that do not allow dilution of DWW in different parts of the system.

Reuse of DWW with supply in irrigation channels became widespread in the Kuban and the Crimea. On the irrigation system can be detected points at which it is possible to pump water from reservoirs in rice irrigation channels. This method is effective when in the rice system is achieved a high level of automation of farm and inter-farm water distribution. The salinity of water that is recycled and mixed with fresh water is controlled.

Partial reverse use of DWW is the most perspective in rice irrigation systems. This method consists in the fact that DWW are accumulated in storage ponds or water reservoirs with subsequent water supply at the head of the system in inter-farm channel. After mixing in a channel with water that is taken from a river or reservoir, the flow is directed to irrigation. Such a system is equipped with automation devices of water 
regulation, control and communications. It enables to manage the process and ensures the most efficient use of DWW in rice systems.

When revolving cycles are growing, the mineralization of mixed irrigation water is increasing. Water mineralization doesn't have to exceed the threshold limit value. It is necessary to take out some DWW and then divert them in water receiver. The advantage of this method, besides significant savings of water, is its environmental safety.

The research $[11,12]$ has shown that while holding the runoff from rice systems in buffer tanks during the month, the destruction of herbicides to toxicological dangerous values happens. Furthermore, pesticides that are carried into the soil environment with DWW are exposed to the processes that can reduce the content of toxicants in them. These processes include the effect of soil microorganisms and ferments, their adsorption with colloidal complex of soils, pesticides distillation with water vapor and their transfer to a gaseous state, their collapse under the influence of ultraviolet radiation, filtration.

The quickness of destruction increases under the influence of solar radiation and artificial aeration. Afterpurification of sewage water is also carried out in interaction with aquatic vegetation ("bioplato" from reed, cattail), which is planted in basin-storages. Higher aquatic plants actively absorb pesticides and nutrients [10, 13].

Conducted long-term studies in the Danube RIS have shown that even under optimal irrigation norm per hectare of rice crops in the collector-drainage network gets 6-10 thousand $\mathrm{m}^{3}$ of water with salinity less than $2 \mathrm{~g} / \mathrm{L}$. Increased salinity of DWW can be in the first flooding of rice and during harvest. Throughout all the irrigation period the mineralization of waste water does not exceed $3 \mathrm{~g} / \mathrm{L}$ (maximum) and ranges mostly from 0.6 to $1.7-1.8 \mathrm{~g} / \mathrm{L}$.

To study the possibility of using DWW in Danube rice system on irrigation, was hold an evaluation of water that is supplied for irrigation by mixing fresh water with DWW in different proportions.

Such variants were estimated:

1) possibility to use DWW without dilution;

2) possibility to use DWW with their dilution with fresh water in a ratio of 1:2;

3) possibility to use DWW with their dilution with fresh water in a ratio of $1: 1$;

4) possibility to use DWW with their dilution with fresh water in a ratio of 2:1;

5) irrigation with fresh water.

The research has shown that when creating of water dams in sprinklers and household sewage the mineralization of DWW is 1.0-1.7 g/L. We had evaluated the suitability of water for irrigation, when diluting DWW and fresh river water with a help of methods of Budanov, Antipov-Karataev and Kader, MozheikoVorotnik, and U.S. Department of Agriculture (for sodium adsorption ratio SAR). Variants of dilution in such ratios were considered (table 1): a) 1:2; b) 1:1; c) 2:1.

The evaluation of irrigation water on mentioned the above methods has shown that at mineralization of DWW $1.35 \mathrm{~g} / \mathrm{L}$ and mineralization of the Danube water $0.29 \mathrm{~g} / \mathrm{L}$, most suitable for irrigation is the irrigation water that is formed by dilution of DWW and fresh water in the ratio from 1:1 to 1:2. 
Table 1. Chemical composition of DWW at its dilution with fresh water

\begin{tabular}{|c|c|c|c|c|c|c|c|}
\hline \multirow{3}{*}{$\begin{array}{l}\text { Total } \\
\text { mineralization, } \\
\text { g/L }\end{array}$} & \multicolumn{6}{|c|}{ Ion concentration } & \multirow{3}{*}{ Unit } \\
\hline & \multicolumn{3}{|c|}{ Anion } & \multicolumn{3}{|c|}{ Cation } & \\
\hline & $\mathrm{HCO}$ & Cl & so: & $\mathrm{Ca}$ & Mg & $\mathrm{Na}+\mathrm{K}$ & \\
\hline \multicolumn{8}{|l|}{ Dilution 1:2 } \\
\hline \multirow{2}{*}{0.70} & 4.10 & 4.62 & 1.58 & 3.45 & 3.25 & 3.6 & $\mathrm{mEq} / \mathrm{L}$ \\
\hline & 0.244 & 0.161 & 0.076 & 0.069 & 0.039 & 0.083 & $g / L$ \\
\hline \multicolumn{8}{|l|}{ Dilution 1:1 } \\
\hline \multirow{2}{*}{0.82} & 3.67 & 6.66 & 2.45 & 3.36 & 3.33 & 6.09 & $\mathrm{mEq} / \mathrm{L}$ \\
\hline & 0.223 & 0.233 & 0.118 & 0.066 & 0.04 & 0.14 & $g / L$ \\
\hline \multicolumn{8}{|l|}{ Dilution 2:1 } \\
\hline \multirow{2}{*}{0.99} & 3.92 & 8.68 & 3.13 & 3.61 & 4.14 & 7.98 & $\mathrm{mEq} / \mathrm{L}$ \\
\hline & 0.239 & 0.304 & 0.3 & 0.144 & 0.099 & 0.184 & $g / L$ \\
\hline
\end{tabular}

When backwaters in channels of drainage network are not done, DWW mineralization may be increased to $3 \mathrm{~g} / \mathrm{L}$. In this case most suitable for irrigation of rice is water, which is formed by dilution of DWW and fresh water in a ratio 1:3. The results of our research show that DWW diluted with fresh water can be used for irrigation, starting with the period when the cards are flooded again after rice comes up. We found that in such mode supply of DWW for irrigation on research cards of Krasnodar type (CKT) and card checks with drainage (CCD) that were placed on the system of channel P-2 of Kiliya rice system, stocks of salts were significantly decreasing in both soil and in groundwater (table 2).

Table 2. Salt balance of DWW and card checks with drainage during irrigation with brackish water (on average over five years of research)

\begin{tabular}{|l|c|c|c|c|}
\hline \multirow{2}{*}{\multicolumn{2}{|c|}{ Elements of salt balance }} & \multicolumn{3}{c|}{ Distance between drainages $=250 \mathrm{~m}$} \\
\cline { 2 - 5 } & \multicolumn{2}{|c|}{ CCD } & \multicolumn{2}{c|}{ CKT } \\
\cline { 2 - 5 } & t/ha & $\%$ & t/ha & $\%$ \\
\hline Stocks of salts in soil in April 1.2 m & 41.49 & 41.22 & 38.42 & 38.55 \\
\hline Stocks of salts in the groundwater in a layer 1.8 m & 48.58 & 48.28 & 51.04 & 51.19 \\
\hline Income of salts with irrigation water & 9.09 & 9.04 & 8.80 & 8.83 \\
\hline Income of salts with fertilizers & 1.46 & 1.46 & 1.43 & 1.43 \\
\hline Total salts in the balance layer (3m) in April & 100.62 & 100.0 & 99.69 & 100.0 \\
\hline Stocks of salts in soil in November 1.2 m & 32.33 & 32.13 & 37.65 & 37.78 \\
\hline Stocks of salts in the groundwater in November in layer 1.8 m & 34.82 & 34.60 & 37.76 & 37.88 \\
\hline Removal of salts with drainage water & 27.76 & 27.59 & 21.90 & 21.96 \\
\hline Removal of salts with waste water & 1.77 & 1.76 & 2.20 & 2.21 \\
\hline Removal of salts with harvest & 1.25 & 1.25 & 1.15 & 1.15 \\
\hline Salt exchange with the lower horizons & 2.69 & 2.67 & -0.97 & -0.98 \\
\hline Total salts in the balance layer (3 m) in November & 100.62 & 100.0 & 99.69 & 100.0 \\
\hline
\end{tabular}

The peculiarity of the Danube RIS is that they are situated on dicked areas. Pumping stations supply water for irrigation from the river Danube on these RIS. Also pumping stations remove DWW outside each of rice systems into the Danube (figure 1a). Therefore, to supply water for irrigation and to remove DWW annually are expended considerable energy resources.

Considering the fact that for irrigation can be used fresh water diluted with DWW in ratio from 1:1 to 1:2, we propose such scheme to supply and remove water for each module of Danube RIS, which will significantly save energy resources (figure $1 \mathrm{~b}$ ). In such scheme DWW on the penstock (6) are supplied into the pool (7), from which fall into the forebay (14) and then are delivered for irrigation. 


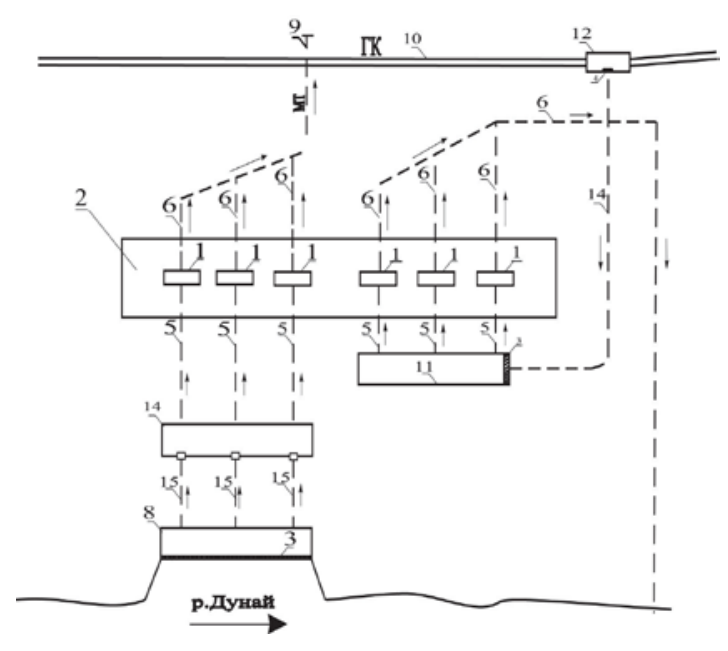

a)

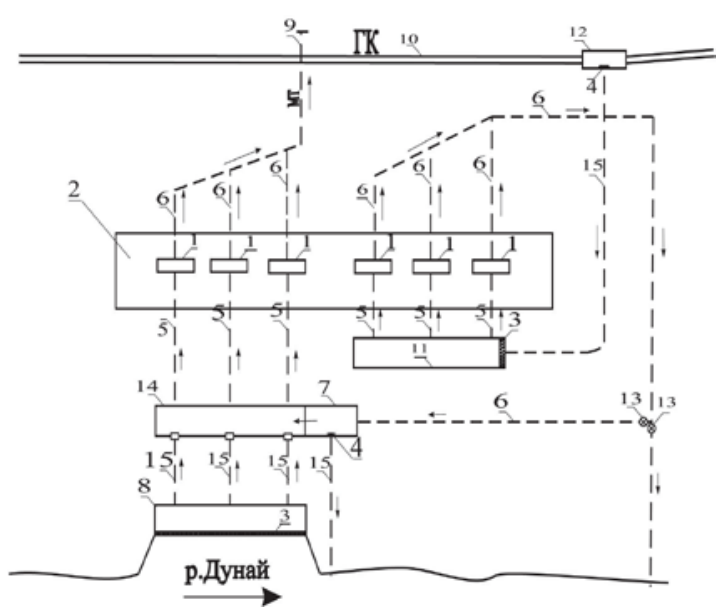

b)

Figure.1. Schemes of water supply and drainage on Danube RIS: a) existing; b) proposed: 1- pump; 2 pumping station; 3 - sludge rake; 4 - sluice; 5- suction pipe; 6 - penstock; 7 - pool to supply DWW for irrigation; 8 - fresh water intake; 9 - trunk pipeline that supplies water on irrigation; 10 - main spillway channel; 11- DWW intake; 12- pool for DWW storage; 13 - damper; 14 - forebay; 15 - low-pressure pipeline.

Reconstruction of water intake unit at the proposed scheme requires minimal costs related to arrangement of the pool for dilution of DWW with fresh water from the Danube (7), two short dampers and short area of penstock with length to $20 \mathrm{~m}$.

\section{Conclusions}

Using DWW on rice irrigation, first of all, reduces pollution of irrigation sources by nutrients and residues of herbicides and insecticides that are not fully decomposed. Secondly, there is no need for pumping large quantities of fresh water for irrigation of rice, which results in saving of fresh water and electricity. Using DWW in Kiliya RIS can lead to energy savings up to 700,000 kWh. Calculations of economic efficiency of water circulation technology in the Danube RIS with DWW dilution with fresh water in the ratio of 1:1 showed that the net profit will amount to $26266.5 \mathrm{UAH} / \mathrm{ha}$, while the dilution in the ratio of $1: 2$ - to $26161.5 \mathrm{UAH} / \mathrm{ha}$. Complementary net profit will accordingly amount to $1337.8 \mathrm{UAH} / \mathrm{ha}$ and $1231.5 \mathrm{UAH} / \mathrm{ha}$. The most perspective technique to use DWW in rice irrigation systems is their reuse with dilution with fresh water at a ratio of 1:1 or 1:2. This ratio corresponds to most indicators for which was done an evaluation of water that is supplied for irrigation. Also this ratio does not lead to deterioration of soil salt regime.

\section{References}

1. Aleksashkin, I.V. (2007). Vozdeistvie melioratsii na okruzhaiushchie prirodnye ekosistemy Sivasha [The impact of melioration on the surrounding ecosystems of Sivash]. Zapiski obshchestva heoekolohov Notes of geoecologists society. Symferopol: Obshchestvo heoekolohov, 9, 35-38 [in Russian].

2. Tuong T.P. Increasing water-use efficiency in rice production: Farmlevel perspectives / T.P. Tuong, S.I. Bhuiyan // Agricultural Water Management. —1999. - № 40. — P. 117-122 [in English].

3. Lozovitskii, P.S., Musienko, B.A. (1987). Vozmozhnost ispolzovania drenazhno-sbrosnykh vod risovykh system dlia oroshenia kormovykh kultur na Krasnoznamenskoi orositelnoi sisteme [The ability to use drainage and wastewater in rice systems for irrigation crops in Krasnoznamensk irrigation system]. Obespechenie ekolohicheskoi nadezhnosti meliorativnykh obiektov — Providing of environmental reliability of meliorative objects. Kyiv: Urozhai, 180-190 [in Russian].

4. Wu D.P. Experiment study of irrigation techniques and water requirement of rice / D.P. Wu, T.E. Wu, Y.X. Wu // Irrigation and Drainage and Small Hydropower Station. — 1995. — №11. — P. 11—15.

5. Vrochynskii, K.K., Makovskii, V.N. (1979). Primenenie pestitsidov i okhrana okruzhaiushchei sredy [The use of pesticides and environmental protection]. Kyiv: Vyshcha shkola [in Russian]. 
6. Kovalov, S.V., Kozishkurt, M.Y., Kozishkurt, S.M. (2004). Neobkhidnist ta mozhlyvist zberezhennia rysovykh system Ukrainy [The need and the ability to save rice systems of Ukraine]. NUWEE bulletin, 4 (28), 41-49 [in Ukrainian].

7. Babenko, Y.A., Musienko, B.A., Starodub, V.V. (1984). Zashchita zalivov Chernoho moria ot zahriaznenia drenazhnymi vodami [Protection of Black Sea bays from drainage pollution]. Okhrana prirody pri proektirovanii meliorativnykh i vodokhoziaistvennukh system [Protection of nature in the design of meliorative and water management systems] - Nauchnye Trudy Soiusvodproekt - Scientific works of Soiusvodproekt. Moscow, 56-61 [in Russian].

8. Dudchenko, V.V., Vozhehova, R.A., Shpak, D.V. et al. (2008). Puti reshenia problem pri vyrashchivanii risa $v$ ahroekosistemakh umerennoho klimata [Ways to solve the problems in rice agro-ecosystems in temperate climate]. Proceedings from Mezhdunarodnaia nauchnaia konferentsia (4-8 avhusta 2008 hoda) International Scientific Conference. Scadovsk: UAAN, Institut risa [in Russian].

9. Morozov, V.V., Kornberher, V.H., Dudchenko, K.V. (2010). Vykorystannia drenazhnykh vod rysovykh zroshuvalnykh system dlia polyvu silskohospodarskykh kultur [The use of drainage water for rice irrigation systems for crop watering]. Kherson: Kolos, $54-56$ [in Ukrainian].

10. Skripchinskaia, L.V. (1980). Ris $v$ delte Dunaia [Rice in the Danube Delta]. Odessa: Maiak [in Russian].

11. Taybe, P.R., Baranova A.H. (1983). Khimia i mikrobiolohia vody [Chemistry and microbiology of water]. Moscow: Vysshaia shkola [in Russian].

12. Melnikov (Eds.). (1985). Spravochnik po pestitsydam [Guide to Pesticides]. Moscow: Khimia [in Russian].

13. Tuliakova, Z.F. (1978) Ris na zasolennykh zemliakh [Rice on saline lands]. Moscow: Kolos [in Russian]. 